\title{
Deep subduction of felsic rocks hosting UHP lenses in the central Saxonian Erzgebirge: Implications for UHP terrane
}

\section{exhumation}

\author{
Jan Schönig $^{1 *}$, Hilmar von Eynatten ${ }^{1}$, Guido Meinhold ${ }^{1,2}$, N. Keno Lünsdorf ${ }^{1}$, Arne P. \\ Willner $^{3}$, Bernhard Schulz ${ }^{4}$ \\ ${ }^{1}$ Geoscience Center Göttingen, University of Göttingen, Goldschmidtstraße 3, 37077 Göttingen, \\ Germany \\ ${ }^{2}$ School of Geography, Geology and the Environment, Keele University, Keele, Staffordshire, ST5 \\ $5 B G, U K$ \\ ${ }^{3}$ Institute of Geology, Mineralogy and Geophysics, Ruhr-University Bochum, Universitätsstraße \\ 150, 44780 Bochum, Germany \\ ${ }^{4}$ Institute for Mineralogy, TU Bergakademie Freiberg, Brennhausgasse 14, 09596 Freiberg, \\ Germany \\ *jan.schoenig@uni-goettingen.de
}

\begin{abstract}
Contrasting metamorphic conditions determined by chemical geothermobarometric investigations of ultrahigh-pressure (UHP) lenses surrounded by high-pressure (HP) and medium-pressure (MP)
\end{abstract}


felsic country rocks are an enigmatic feature of UHP terranes. One of the major questions arising is whether the UHP lenses and the country rocks are a product of different peak metamorphic conditions corresponding to different maximum depth or whether country rocks also experienced UHP conditions but equilibrated and/or re-equilibrated at a different metamorphic stage. Here we address this question to the central Saxonian Erzgebirge in the northwestern Bohemian massif, Germany. In order to screen the variety of garnet from lithologies occurring in the study area, we analyzed the detrital garnet record from seven modern stream sands. In addition to 700 inclusionbearing garnet grains previously studied from the $125-250 \mu \mathrm{m}$ grain-size fraction, we analyzed the $63-125$ and $250-500 \mu \mathrm{m}$ fractions and extended the dataset to overall 2100 inclusion-bearing grains. The new findings of coesite and diamond inclusions in several garnet grains, which are in compositional contrast to garnet of the known UHP lenses but match with those of the felsic country rocks, show that considerable parts of the country rocks underwent UHP metamorphism. Melt inclusions containing cristobalite, kokchetavite, and kumdykolite in garnet derived from the country rocks point to partial melting and re-equilibration during exhumation at HP/HT conditions. Although an amalgamation of rocks which reached different maximum depth may be responsible for some of the contrasting peak metamorphic conditions, the mineralogical evidence for UHP conditions in the felsic country rocks surrounding the UHP lenses proves a largely coherent slab subducted to UHP conditions. Furthermore, the presence of coesite in the subducting voluminous felsic crust and its transformation to quartz during exhumation have great implications for buoyancy development during the metamorphic cycle, which may explain the high exhumation rates of UHP terranes. 


\section{Keywords}

Ultrahigh-pressure metamorphism; garnet; inclusions; coesite; diamond

\section{Introduction}

The occurrence of metamafic and metasedimentary coesite- and/or diamond-bearing lenses within large volumes of high-pressure (HP) and medium-pressure (MP) gneissic and schistose felsic country rocks is a common feature of ultrahigh-pressure (UHP) terranes (Liou et al., 2009). To understand the geodynamic context of these terranes, it is particularly important to examine whether the country rocks and UHP lenses share a joint pressure-temperature $(\mathrm{P}-\mathrm{T})$ path or represent different units amalgamated during exhumation. This is still a matter of debate for many UHP terranes due to the strong ductile deformation obscuring the structural relations and more importantly, the lack of geothermobarometric evidence that the country rocks experienced UHP metamorphism.

In the central Saxonian Erzgebirge of the northwestern Bohemian Massif in Germany, UHP rocks locally occur as lenses within quartzo-feldspathic country rocks (e.g., Nasdala and Massonne, 2000; Massonne, 2001). The high contrast in peak metamorphic conditions of the adjacent HP/HT (high-temperature) gneisses (HP granulite facies; $2.1 \mathrm{GPa}$ at $\sim 830^{\circ} \mathrm{C}$; Willner et al., 1997; Tichomirowa et al., 2018) compared to the coesite- and diamond-bearing UHP lenses has been interpreted as a mixture of rocks which reached different maximum depth and were amalgamated during exhumation (e.g., Massonne, 2005, 2011). Alternatively, both the UHP lenses and the country rocks might have been subducted to UHP conditions as a coherent slab but 
the felsic country rocks either have not equilibrated at peak conditions or re-equilibrated and recrystallized during HT decompression (Gose and Schmädicke, 2018; Faryad and Cuthbert, 2020). In terms of pervasive re-equilibration, rare relictic mineral cores and/or preserved inclusions of coesite and diamond in resistant host minerals may be the only witnesses for a precursor UHP metamorphic event.

Testing this hypothesis is challenging considering the small inclusions to be found within host minerals from huge volumes of country rocks, in particular when outcrops are rather limited like in the Erzgebirge. Nevertheless, by investigating inclusions in the detrital record advantage of natural processes can be taken to systematically sample a mixture of host minerals from various rocks occurring in the sampled catchments (Schönig et al., 2018a). The application of this technique to the $125-250 \mu \mathrm{m}$ detrital garnet grain-size fraction in the central Saxonian Erzgebirge has already demonstrated that UHP rocks occur frequently and dispersed within the country rocks rather than being restricted to a few localities (Schönig et al., 2019). However, hints for the involvement of the country rocks in the UHP metamorphic cycle are sparse in the analyzed grain-size fraction.

Studies comparing detrital garnet composition and grain size have shown that provenance information may be missed by focusing on a narrow grain-size window (Krippner et al., 2015; Krippner et al., 2016). In order to elucidate whether the lack of UHP garnet from the country rocks in the central Erzgebirge can be attributed to contrasting peak metamorphic conditions or whether it is an effect of the narrow grain-size window analyzed so far, we considerably extend the mineral inclusion and chemical data of garnet grains from modern sands previously studied by Schönig et al. (2019) by investigating the 63-125 $\mu \mathrm{m}$ and $250-500 \mu \mathrm{m}$ grain-size fractions. 
Based on (i) the compositional contrast of several coesite- and diamond-bearing garnet grains to those from known UHP rocks of the study area and (ii) the occurrence of melt inclusions containing cristobalite, kokchetavite, and kumdykolite in garnet grains derived from felsic rocks, we demonstrate that considerable parts of the felsic country rocks underwent a precursor UHP metamorphic stage but re-equilibrated at HP/HT conditions during exhumation. In addition, we discuss the implications of these findings on conceptual models for the exhumation of UHP terranes.

\section{Geological framework and samples}

The crystalline complex of the Saxonian Erzgebirge formed as part of the European Variscides resulting from the collision of Gondwana (Armorican Terrane Assemblage) and Laurussia (Laurentia, Baltica, Avalonia, Ganderia) during the Variscan orogeny (e.g., Kroner and Romer, 2013; Fig. 1A). Its dome structure consists of a stack of composite tectonometamorphic units of contrasting peak metamorphic conditions. The highest $\mathrm{P}-\mathrm{T}$ conditions are recorded in the "Gneiss-Eclogite Unit" in the central part of the crystalline complex, a heterogeneous nappe in intermediate position of the nappe stack containing MP, HP, and UHP rocks (Willner et al., 1997; Willner et al., 2000; Fig. 1B). Within this nappe, two areas containing HP rocks and one area containing UHP rocks can be distinguished (e.g., Schmädicke et al., 1995; Gose and Schmädicke, 2018).

Within the HP/UHP nappe, seven modern sand samples were taken from tributaries draining the area around the Saidenbach reservoir (Fig. 1C). Geographic coordinates of sampling localities are 
given in Schönig et al. (2019). The study area mainly comprises foliated quartzo-feldspathic HP/HT country rock gneisses (e.g., Willner et al., 1997), which host numerous lenses of eclogite (e.g., Liati and Gebauer, 2009). Some eclogite lenses contain inclusions of coesite indicating an UHP origin (e.g., Massonne, 2001; O’Brien and Ziemann, 2008; Gose and Schmädicke, 2018). In addition, at the eastern shore of the Saidenbach reservoir diamond-bearing paragneiss lenses occur (e.g., Nasdala and Massonne, 2000). These differ from the country rock gneisses by the virtual absence of foliation and the homogenous appearance of mm-sized diamond-bearing garnet (e.g., Massonne, 2011). While most samples represent small catchment areas $\left(<1\right.$ to $<20 \mathrm{~km}^{2}$; Schönig et al. 2019) the most distal sample from the Flöha River (JS-Erz-14s) represents a relatively large drainage area $\left(>500 \mathrm{~km}^{2}\right)$ comprising not only additional lithologies from the “Gneiss-Eclogite Unit”, i.e., micaschists and ultramafic rocks, but also from the surrounding nappes of lower metamorphic grade (e.g., Willner et al., 2000; Fig. 1B).

\section{[insert Figure 1]}

\section{Methods}

Mineral separation, sample preparation, and analytical procedures were performed at the Geosciences Center at the University of Göttingen. Sand samples were wet sieved to extract the grain-size fractions. The $63-125 \mu \mathrm{m}$ and $250-500 \mu \mathrm{m}$ fractions were treated with acetic acid to remove carbonate contents if present, and the heavy mineral fraction was separated by centrifugation using sodium polytungstate with a density of $\sim 2.85 \mathrm{~g} \mathrm{~cm}^{-3}$. Heavy mineral concentrates were embedded in synthetic mounts using a bonding epoxy. Mounts were grounded 
with silicon carbide abrasive paper and polished in five steps with $\mathrm{Al}_{2} \mathrm{O}_{3}$ abrasives in water suspension up to the finest step with a particle size of $0.05 \mu \mathrm{m}$.

Mineral inclusions $\geq 2 \mu \mathrm{m}$ in 100 inclusion-bearing detrital garnet grains from both the $63-125$ $\mu \mathrm{m}$ and $250-500 \mu \mathrm{m}$ grain-size fraction were investigated by Raman spectroscopy. Inclusion identification follows the method described in Schönig et al. (2018a, 2018b) by using a Horiba Jobin Yvon XploRA Plus Raman spectrometer. Measurement conditions include a $532 \mathrm{~nm}$ laser, a $18001 \mathrm{~mm}^{-1}$ grating, confocal hole diameter and slit of $100 \mu \mathrm{m}$, and a $100 \times$ long working distance objective with a numerical aperture of 0.8. Spectral Raman images of specific inclusion types were prepared by using a WITec alpha300R fiber-coupled ultra-high throughput Raman spectrometer. Conditions include a $532 \mathrm{~nm}$ laser, an automatically adjusted laser power of 30 $\mathrm{mW}$, a $3001 \mathrm{~mm}^{-1}$ grating, a 100× long working distance objective with a numerical aperture of 0.75 , a step size of $200 \mathrm{~nm}$, and between $0.5 \mathrm{~s}$ and $2.0 \mathrm{~s}$ acquisition time per spectrum.

Garnet compositions of all identified coesite- and diamond-bearing garnet grains were determined at nine measurement spots per grain by electron microprobe analysis, except garnet \#32 of the 250-500 $\mu \mathrm{m}$ fraction from sample JS-Erz-3s which composition was determined at a single spot. The composition of cristobalite-, kokchetavite-, and kumdykolite-bearing grains was also determined at one measurement spot per grain. Electron microprobe analysis (EMPA) was performed using a JEOL JXA 8900 RL microprobe. Before analysis, all samples were coated with carbon to ensure conductivity. Measurement conditions include an accelerating voltage of $15 \mathrm{kV}$, a beam current of $20 \mathrm{nA}$, and counting times of $15 \mathrm{~s}$ for silicon, magnesium, calcium, iron, and aluminum, and $30 \mathrm{~s}$ for titanium, chromium, and manganese. The multivariate garnet 
discrimination scheme after Tolosana-Delgado et al. (2018) was applied by using the prior 'equal-M'.

Results were integrated with data from the previously studied 125-250 $\mu \mathrm{m}$ fraction making up a dataset of 2100 inclusion-bearing garnet grains (7 samples á 3 grain-size fractions á 100 garnet grains). Mineral inclusion assemblages and compositions of all coesite-, diamond-, cristobalite-, kokchetavite-, and kumdykolite-bearing garnet grains are given in Table A.1 (see Appendix A). Chemical compositions were compared with literature data of garnet from eclogite, diamondbearing paragneiss, country rock gneiss, and garnet micaschist, complemented by previously unpublished garnet data from these rock types (Table A.2, see Appendix A).

\section{Results}

\subsection{Coesite-bearing detrital garnet}

From the studied detrital garnet grains of the central Saxonian Erzgebirge, in total 93 out of 2100 inclusion-bearing grains contain coesite (Table 1). Compared to the $125-250 \mu \mathrm{m}$ fraction (Schönig et al., 2019), the larger analyzed grain-size window reveals that coesite inclusions occur in all sampled catchments. Coesite inclusions are mainly monomineralic, whereas larger inclusions $>10 \mu \mathrm{m}$ often show partial transformation to quartz at the inclusion/host boundary. Former coesite inclusions which have been completely transformed to polycrystalline quartz are not considered, as to identify the polycrystalline character of small inclusions a detailed Raman imaging of all quartz inclusions would be required. The amount of coesite-bearing garnet grains varies between individual samples and between the analyzed grain-size fractions of each sample 
(Table 1). However, variability with grain size is not systematic, with coesite-bearing garnet being enriched in the $125-250 \mu \mathrm{m}$ and $250-500 \mu \mathrm{m}$ fractions of samples JS-Erz-3s, $-13 \mathrm{~s}$, and $14 \mathrm{~s}$, and in the $63-125 \mu \mathrm{m}$ fraction of samples JS-Erz-5s and $-8 \mathrm{~s}$, whereas JS-Erz-6s and $-9 \mathrm{~s}$ do not show a clear trend.

\section{[insert Table 1]}

Chemical compositions of the detrital coesite-bearing garnet grains show that the majority of these grains derive from rocks similar to the known UHP rocks of the area, i.e., eclogite and paragneiss lenses (Fig. 2). However, the compositions of several grains in the $\mathrm{X}_{\mathrm{Fe}}-\mathrm{X}_{\mathrm{Ca}}-\mathrm{X}_{\mathrm{Mg}}$ ternary diagram plot outside the $95 \%$ confidence ellipsoids of the known UHP rocks. For the purpose of this study, we will focus on those garnet grains which show the highest compositional contrast to those of the UHP eclogite and paragneiss lenses.

\section{[insert Figure 2]}

From the coesite-bearing garnet grains of the 63-125 $\mu \mathrm{m}$ fraction, garnet grains \#35 and \#44 of sample JS-Erz-3s, garnet \#53 of JS-Erz-8s, and garnet \#92 and \#151 from JS-Erz-6s show the highest compositional contrast. In the 125-250 $\mu \mathrm{m}$ fraction, this is garnet \#153 from JS-Erz-13s, and in the 250-500 $\mu \mathrm{m}$ fraction, these are garnet grains \#46 and \#59 from JS-Erz-13s and garnet \#30 from JS-Erz-14s (Fig. 2, $\mathrm{X}_{\mathrm{Fe}}-\mathrm{X}_{\mathrm{Ca}}-\mathrm{X}_{\mathrm{Mg}}$ diagrams). Their compositional difference is only insufficiently displayed in the classical $\mathrm{X}_{\mathrm{Fe}}-\mathrm{X}_{\mathrm{Ca}}-\mathrm{X}_{\mathrm{Mn}}$ and $\mathrm{X}_{\mathrm{Mn}}-\mathrm{X}_{\mathrm{Ca}}-\mathrm{X}_{\mathrm{Mg}}$ ternary diagrams due to the low manganese content of all garnet grains. This, however, becomes more obvious after perturbation (i.e., centering) of the data after von Eynatten et al. (2002) where several garnet

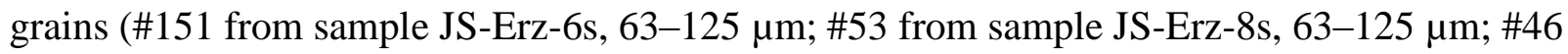


and \#59 from sample JS-Erz-13s, 250-500 $\mu \mathrm{m}$; \#30 from sample JS-Erz-14s, 250-500 $\mu \mathrm{m}$ ) show clear contrast to the local eclogite and diamond-bearing paragneiss lenses (Fig. A.1, see Appendix A).

To use all chemical variables determined by EMPA, the multivariate garnet discrimination scheme after Tolosana-Delgado et al. (2018) was applied. This scheme is based on a large compositional dataset of a variety of garnet-bearing rocks. It is designed for sedimentary provenance studies where the host-rock composition is not available. Solely based on garnet composition, the algorithm assigns garnet grains with a certain probability to major host-rock types. The results show that all garnet grains derive from metamorphic rocks with a probability of $>99 \%$. Furthermore, for metamorphic garnet the algorithm provides probabilities of belonging to rocks of different metamorphic grade, simplified as amphibolite-, granulite-, and eclogite-facies rocks, independent from their composition. These probabilities for the single coesite-bearing garnet grains are visualized in ternary diagrams for the analyzed grain-size fractions (Fig. 2). All aforementioned garnet grains showing chemical contrast to the known UHP rocks in one or more of the ternary major element diagrams yield distinctly higher probabilities of being derived from lower-pressure (i.e., amphibolite-facies) metamorphic rocks.

Resulting from these observations, and considering the elements having strong effects on the multivariate discrimination approach, the chemical contrast of the nine coesite-bearing detrital garnet grains to garnet from the known UHP rocks of the area can be more easily expressed by their higher iron to magnesium and/or manganese to magnesium ratios in a simple scatter plot (Fig. 2). These garnet grains compositionally overlap with those from the country rock gneiss. As micaschist occurs in the large catchment of sample JS-Erz-14s, and garnet from this rock type 
show a huge compositional spread with the $95 \%$ confidence ellipse covering the entire scatter plot, the micaschist can be also taken into consideration as a possible source for garnet \#30 from the $250-500 \mu \mathrm{m}$ fraction of this sample.

\subsection{Diamond-bearing detrital garnet}

Diamond-bearing detrital garnet is dominantly concentrated in sample JS-Erz-9s where 53 garnet grains containing diamond have been identified out of the 300 inclusion-bearing grains analyzed from this sample (Table 1). Their amount increases with increasing grain size. In addition, diamond-bearing garnet is not restricted to this sample taken proximal to the known diamondbearing paragneiss lenses. Sample JS-Erz-14s, which represents the largest catchment investigated, contains also diamond-bearing garnet in the $250-500 \mu \mathrm{m}$ fraction. It should, however, be noted that the catchment of sample JS-Erz-14s encompasses that of sample JS-Erz9s and thus, diamond-bearing garnet in sample JS-Erz-14s not necessarily point to another diamond-bearing source. Many of the diamond inclusions are monomineralic, but often they occur in polyphase inclusions together with phyllosilicates (mainly phlogopite-biotite), rutile, graphite, and quartz. More rarely, plagioclase, apatite, and carbonates are present in these polyphase inclusions (Table A.1, see Appendix A).

The majority of diamond-bearing detrital garnet grains shows compositional overlap with garnet from the diamond-bearing paragneiss (Fig. 3). Several of them, however, are clearly distinct like garnet \#66 and \#123 of the 125-250 $\mu \mathrm{m}$ fraction from sample JS-Erz-9s, garnet \#16 and \#87 of the 250-500 $\mu \mathrm{m}$ fraction from JS-Erz-9s, and garnet \#29 from sample JS-Erz-14s. These garnet 
grains overlap compositionally with garnet from local eclogite, except for garnet \#66 of the 125$250 \mu \mathrm{m}$ fraction from JS-Erz-9s. This is supported by comparing the manganese contents relative to iron, calcium, and magnesium in the perturbed ternary plots (Fig. A.2, see Appendix A). Similar to the coesite-bearing garnet, some of the exceptional diamond-bearing garnet grains show a slightly higher probability of belonging to lower-pressure metamorphic sources (garnet grains \#16 and \#87 of the 250-500 $\mu \mathrm{m}$ fraction from JS-Erz-9s; Fig. 3). This trend is even more pronounced for garnet \#29 from JS-Erz-14s.

\section{[insert Figure 3]}

As for the coesite-bearing garnet, the chemical contrast of several diamond-bearing garnet grains to the known UHP rocks can be well-observed in the scatter plots (Fig. 3). Garnet \#66 from the 125-250 $\mu \mathrm{m}$ fraction as well as \#16 and \#87 of the $250-500 \mu \mathrm{m}$ fraction from sample JS-Erz-9s, and garnet \#29 from the 250-500 $\mu \mathrm{m}$ fraction of JS-Erz-14s show higher manganese to magnesium and/or iron to magnesium ratios than garnet from eclogite and diamond-bearing paragneiss lenses. In contrast, the composition of garnet \#123 of the $125-250 \mu \mathrm{m}$ fraction from JS-Erz-9s is similar to eclogitic garnet. Consequently, this garnet may be derived from an eclogite intercalated with the diamond-bearing paragneiss and cannot be assigned to the country rock gneisses.

\subsection{Cristobalite-, kokchetavite-, and kumdykolite-bearing detrital garnet}

Apart from UHP mineral inclusions, particular attention was paid to inclusion types which have been rarely reported from UHP terranes namely cristobalite, the tetragonal $\mathrm{SiO}_{2}$ polymorph, 
kokchetavite, the hexagonal $\mathrm{KAlSi}_{3} \mathrm{O}_{8}$ polymorph, and kumdykolite, the orthorhombic $\mathrm{NaAlSi}_{3} \mathrm{O}_{8}$ polymorph (Hwang et al., 2004; Hwang et al., 2009).

Inclusions containing cristobalite were identified in 26 out of the 2100 inclusion-bearing detrital garnet grains (Table A.1, see Appendix A). They occur in all analyzed samples. Although several cristobalite inclusions primarily seem to be monomineralic, all cristobalite inclusions that were mapped by high-resolution Raman imaging show a polymineralic character. In the polyphase inclusions cristobalite occurs together with hydrous phases, mainly white mica and phlogopitebiotite but also amphibole. Besides the hydrous phases, the polyphase inclusions often contain carbonates and rarely rutile, graphite, and kokchetavite (see below). In two of the garnet grains, cristobalite inclusions co-exist with inclusions of coesite and quartz, thus, presenting three $\mathrm{SiO}_{2}$ polymorphs in the same grain (e.g., Fig. 4A). In addition, two of the diamond-bearing garnet grains contain inclusions of cristobalite (e.g., Fig. 4B).

\section{[insert Figure 4]}

Kokchetavite was identified in four grains, whereas three of them are from sample JS-Erz-9s and one from JS-Erz-3s. It mainly occurs in polyphase inclusions together with white mica, quartz, cristobalite, carbonates, and apatite (Figs. 4C and 4D). In two garnet grains, kokchetavite coexists with kumdykolite in the same inclusion (e.g., Fig. 4C). Kumdykolite was also observed in another polyphase inclusion in garnet from sample JS-Erz-9s together with phlogopite-biotite, rutile, and cristobalite (Table A.1, see Appendix A).

Although some of the cristobalite-, kokchetavite-, and kumdykolite-bearing garnet grains are within the compositional range of eclogitic garnet, the major proportion of them compositionally 
clearly overlap with garnet of the UHP paragneiss lenses, and all of them match with the quartzofeldspathic country rock gneiss (Fig. 5). As for the coesite- and diamond-bearing garnet, the manganese to magnesium versus iron to magnesium plot further supports this observation and shows that several cristobalite-, kokchetavite-, and kumdykolite-bearing garnet grains match only with garnet compositions of the quartzo-feldspathic country rocks.

\section{[Insert Figure 5]}

\section{Discussion}

The newly identified sediment samples containing coesite- and diamond-bearing garnet, the heterogeneous distribution of coesite-bearing garnet regarding grain size, and the identified UHP garnet grains which compositionally differ from those of the known UHP rocks of the study area show that it is important to consider a larger detrital grain-size window to achieve thorough provenance information from mineral inclusions, especially in terms of UHP source rocks.

Most valuably, garnet compositions of at least nine coesite-bearing garnet grains from five samples (JS-Erz-3s, -6s, -8s, -13s, -14s) as well as at least four diamond-bearing garnet grains from two samples (JS-Erz-9s, -14s) are in clear contrast to garnet compositions of the known UHP rocks in the study area. Instead, they are compositionally similar to garnet from the quartzofeldspathic country rocks. This is the most reasonable source of these garnet grains, because quartzo-feldspathic gneiss is the dominant rock type in the studied catchments. For the coesitebearing garnet \#29 and the diamond-bearing garnet \#30 of the 250-500 $\mu \mathrm{m}$ fraction from sample JS-Erz-14s also micaschist may be considered as a source rock but the major element chemical 
composition of these garnet grains does not allow to discriminate between the country rock gneiss and micaschist.

The chemical contrast of the coesite- and diamond-bearing garnet grains derived from the country rocks is best expressed by their higher iron and/or manganese content compared to magnesium. This is typical for equilibration at lower-grade metamorphic conditions (e.g., Spear, 1993; Cutts et al., 2010), though an UHP stage is confirmed by the inclusions of coesite and/or diamond. Because compositions were determined at nine spots per garnet covering large parts of the entire grain and the chemical contrast is observed for each measurement, a potential bias by zonation is ruled out.

Thus, garnet growth in both the UHP rock lenses and considerable parts of the surrounding country rocks took place at UHP metamorphic conditions during the Variscan orogeny. Furthermore, the occurrence of UHP garnet from the country rocks in six of the seven studied catchments indicates that UHP metamorphism of the country rocks is not locally restricted. Instead, rather large parts of the central Saxonian Erzgebirge appear to be affected by UHP metamorphism. The lower abundance of UHP garnet grains derived from the country rocks compared to those from the known UHP lenses is caused by the much lower modal garnet content in the country rock gneiss compared to high contents in eclogite (15-45 vol\%, Gose and Schmädicke, 2018) and diamond-bearing paragneiss (15-20 vol\%, Nasdala and Massonne, 2001; Massonne, 2003).

The UHP event in the quartzo-feldspathic country rocks was likely not recorded by geothermobarometric approaches due to major element re-equilibration of garnet by rapid 
diffusion during HT exhumation. Even when considering the short period available for diffusional homogenization at HP/HT conditions due to the high exhumation rates (e.g., Kröner and Willner, 1998), the fast diffusion rates at temperature conditions $>800^{\circ} \mathrm{C}$ (as determined for the HP granulite-facies quartzo-feldspathic country rocks; Willner et al., 1997; Tichomirowa et al., 2018) facilitate garnet major element re-equilibration (e.g., Caddick et al., 2010). This agrees with relict garnet zonation patterns reported from the country rocks, which roughly follow the shape of corrosion embayments and cannot be regarded as a prograde feature. However, a precursor prograde stage is recorded by inclusions of white mica and rarely omphacite in garnet (Willner et al., 1997).

The findings of polyphase inclusions containing cristobalite, kokchetavite, and kumdykolite in garnet being mainly derived from felsic lithologies further support the subjection of country rocks to HT conditions. Such inclusions are also called "nanogranitoids" and likely represent melt droplets entrapped during garnet growth at HP/HT conditions (e.g., Cesare et al., 2009; Ferrero et al., 2016; Ferrero et al., 2019). Similar melt inclusions containing kumdykolite and/or kokchetavite have been found in the "Gneiss-Eclogite Unit" drilled in the Eger Crystalline Complex farther south (Kotková et al., 2014) and in the Granulitgebirge farther north (Borghini et al., 2020). The reason for crystal structures other than usual at HP/HT conditions, i.e., quartz, alkali feldspar, and plagioclase, is not yet fully understood. Nevertheless, it is likely related to a combination of (i) the $\mathrm{P}-\mathrm{T}$ conditions within the inclusions that diverge from the external metamorphic conditions due to the different thermoelastic properties of the melt and the garnet host, (ii) rapid crystallization and accompanied abrupt pressure changes within the inclusions, 
and (iii) predetermined nucleation sites given by the host garnet and the first phases crystallizing from the melt (Ferrero and Angel, 2018).

In summary, garnet growth in a considerable part of the felsic country rocks took place at UHP conditions and thus precludes that contrasting geothermobarometric conditions determined for the country rocks and the UHP lenses solely result from different maximum subduction depth. Instead, we interpret the UHP terrane exposed in the central Saxonian Erzgebirge as a largely coherent slab that has been subducted to UHP conditions. However, partial amalgamation with lower-pressure metamorphic rocks during exhumation cannot be precluded; the spatial boundary to rocks unaffected by UHP metamorphism remains elusive.

During deep subduction, the mafic lithologies comprehensively equilibrated under UHP conditions and often preserve this information due to the virtual absence of hydration at HP/HT conditions during exhumation. In contrast, the presence of fluid/melt at HP/HT conditions in the felsic lithologies, as shown by the polyphase cristobalite, kokchetavite, and kumdykolite inclusions containing hydrous phases, caused a strong re-equilibration of the country rocks obscuring their precursor subjection to UHP metamorphic conditions. Based on these observations, the search for relicts of the UHP event in crystalline rock samples of the felsic country rocks in future studies may reveal important new insights regarding the structure and history of the Erzgebirge UHP terrane, given by the ability to perform pseudosection modelling. In addition, extending the search for UHP metamorphism to a wider area is crucial to reveal whether the UHP unit is even much larger in size than formerly expected, as one may speculate based on the findings of coesite and diamond inclusions in the same unit $\sim 45 \mathrm{~km}$ farther south (Kotková et al., 2011). 


\section{Geodynamic implications}

Felsic country rocks surrounding UHP lenses that were subducted to UHP conditions, equilibrated at these conditions, and re-equilibrated at HP/HT conditions is not a unique feature of the Erzgebirge. Instead, based on findings of UHP inclusions in re-equilibrated felsic rocks, this issue has been suggested for several UHP terranes worldwide like the Dabie Shan and Sulu in China (Okay, 1993; Ye et al., 2000), the Greenland Caledonides (Gilotti and Ravna, 2002), and the Scandinavian Caledonides (Klonowska et al., 2017). Due to the presence of coesite inclusions in country rock garnet, it can be expected that coesite was also present as a matrix phase at UHP conditions. Despite the increasing solubility of $\mathrm{OH}$ in coesite with increasing pressure (Mosenfelder, 2000), the preservation of coesite as monomineralic inclusions call for low $\mathrm{OH}$ contents, agreeing with the typical dry nature of UHP terranes (Hermann and Rubatto, 2014). Thus, reaction kinetics of the coesite-to-quartz transformation are strongly reduced during exhumation (Lathe et al., 2005) and under extremely dry conditions, coesite may even survive as a matrix phase (Liou and Zhang, 1996; Liu et al., 2017). Whatever process triggers the initial exhumation, the presence of fluid/melt during re-equilibration at HP/HT conditions, most likely being related to phengite breakdown (e.g., Lang and Gilotti, 2015), facilitates the coesite-toquartz transformation within the large volumes of felsic country rocks (Mosenfelder et al., 2005). This transformation is accompanied by a strong density decrease of the $\mathrm{SiO}_{2}$ component of $\sim 10$ $\%$. Thus, the resulting highly buoyant felsic country rocks can passively transport the unaffected or minor re-equilibrated UHP lenses to lower crustal levels. The high buoyancy may also explain 
the high exhumation rates reported from UHP terranes like the Erzgebirge (Kröner and Willner, 1998; Massonne et al., 2007; Stöckhert et al., 2009).

\section{Conclusions}

The widespread occurrence of coesite and diamond inclusions in detrital garnet from the central Saxonian Erzgebirge as well as coesite- and diamond-bearing garnet grains resembling the chemical composition of garnet from the country rocks demonstrate that UHP metamorphism has not only affected the known metamafic and metasedimentary lenses but also the felsic country rocks. Thus, the HP/UHP terrane of the central Erzgebirge is interpreted as a largely coherent slab subducted to UHP metamorphic conditions during the Variscan orogeny. In contrast to the UHP lenses, the country rocks strongly re-equilibrated at HP/HT conditions during exhumation. This re-equilibration is supported by nanogranitoid inclusions in garnet containing cristobalite, kokchetavite, and kumdykolite. These findings contradict the earlier view of solely different maximum subduction depth to explain contrasting geothermobarometric conditions between very closely related HP country rocks and UHP lenses. Additionally, coesite was present as a matrix phase within the country rocks prior to re-equilibration at HP/HT conditions. This has considerable implications for the understanding of buoyancy development during the subduction and exhumation of UHP terranes and consequently, the rate of exhumation.

\section{Acknowledgements}


This work was supported by the German Research Foundation by DFG grant EY 23/27-1 to H. von Eynatten and G. Meinhold. We thank J.E. Dunklné Nagy, I. Dunkl, and A. Grebe for their support in sample preparation, and A. Kronz for giving access to the electron microprobe. Careful editorial handling by Tim Johnson is gratefully acknowledged.

\section{Author contributions}

Jan Schönig: Conceptualization, Field work, Methodology, Formal analysis, Investigation, Writing - Original draft, Visualization; Hilmar von Eynatten: Conceptualization, Field work, Writing - Review and editing, Supervision, Project administration, Funding acquisition; Guido Meinhold: Conceptualization, Writing - Review and editing, Supervision, Funding acquisition; N. Keno Lünsdorf: Methodology, Validation, Writing - Review and editing; Arne Willner: Resources, Writing - Review and editing; Bernhard Schulz: Resources, Writing - Review and editing.

\section{Competing interest}

The authors declare no competing interest.

\section{Appendix A. Supplementary material}

Supplementary material related to this article can be found on-line at https://doi.org/xxxxxx 
Supplementary files:

Table A.1. Mineral inclusions and composition of coesite-, diamond-, cristobalite-, kokchetavite-, and kumdykolite-bearing detrital garnet grains.

Table A.2. Garnet composition of local crystalline rocks.

Figure A.1. Chemistry of coesite-bearing detrital garnet grains shown in perturbed ternary plots.

Figure A.2. Chemistry of diamond-bearing detrital garnet grains shown in perturbed ternary plots.

\section{References}

Borghini, A., Ferrero, S., O’Brien, P.J., Laurent, O., Günter, C., and Ziemann, M.A. (2020):

Cryptic metasomatic agent measured in situ in Variscan mantle rocks: Melt inclusions in garnet of eclogite, Granulitgebirge, Germany. Journal of Metamorphic Geology, 38, 207234, https://doi.org/10.1111/jmg.12519.

Caddick, M.J., Konopásek, J., and Thompson, A.B. (2010): Preservation of garnet growth zoning and the duration of prograde metamorphism. Journal of Petrology 51, 2327-2347, https://doi.org/10.1093/petrology/egq059.

Cesare, B., Ferrero, S., Salvioli-Mariani, E., Pedron, D., and Cavallo, A. (2009): "Nanogranite" and glassy inclusions: The anatectic melt in migmatites and granulites. Geology 37, 627630, https:// doi.org/10.1130/G25759A.1. 
Cutts, K.A. et al. (2010): Three metamorphic events recorded in a single garnet: Integrated phase modelling, in situ LA- ICPMS and SIMS geochronology from the Moine Supergroup, NW Scotland. Journal of Metamorphic Geology 28, 249-267, https://doi.org/10.1111/j.15251314.2009.00863.x.

Faryad, S.W., and Cuthbert, S.J. (2020): High-temperature overprint in (U)HPM rocks exhumed from subduction zones; A product of isothermal decompression or a consequence of slab break-off (slab rollback)? Earth-Science $\quad$ Reviews 103108, https://doi.org/10.1016/j.earscirev.2020.103108.

Ferrero, S., and Angel, R.J. (2018): Micropetrology: are inclusions grains of truth? Journal of Petrology 59, 1671-1700, https://doi.org/10.1093/petrology/egy075.

Ferrero, S., Ziemann, M.A., Angel, R.J., O’Brien, P.J., and Wunder, B. (2016): Kumdykolite, kokchetavite, and cristobalite crystallized in nanogranites from felsic granulites, OrlicaSnieznik Dome (Bohemian Massif): not evidence for ultrahigh-pressure conditions. Contributions to Mineralogy and Petrology 171, 3, https://doi.org/10.1007/s00410-015-1220$\mathrm{X}$.

Ferrero, S. et al. (2019): A treasure chest full of nanogranitoids: an archive to investigate crustal melting in the Bohemian Massif. Geological Society, London, Special Publications 478, 13 38, https://doi.org/10.1144/SP478.19.

Gilotti, J.A., and Ravna, E.J.K. (2002): First evidence for ultrahigh-pressure metamorphism in the North-East Greenland Caledonides. Geology 30, 551-554, https://doi.org/10.1130/00917613(2002)030<0551:FEFUPM>2.0.CO;2. 
Gose, J., and Schmädicke, E. (2018): Water incorporation in garnet: Coesite versus quartz eclogite from Erzgebirge and Fichtelgebirge. Journal of Petrology 59, 207-232, https://doi.org/10.1093/petrology/egy022.

Hermann, J., and Rubatto, D. (2014): Subduction of continental crust to mantle depth: geochemistry of ultrahigh-pressure rocks in Treatise on Geochemistry, 2nd Edition, Elsevier.

Hwang, S.L. et al. (2004): Kokchetavite: a new potassium-feldspar polymorph from the Kokchetav ultrahigh-pressure terrane. Contributions to Mineralogy and Petrology 148, 380389, https://doi.org/10.1007/s00410-004-0610-2.

Hwang, S.L. et al. (2009): Kumdykolite, an orthorhombic polymorph of albite, from the Kokchetav ultrahigh-pressure massif, Kazakhstan. European Journal of Mineralogy 21, 1325-1334, https://doi.org/10.1127/0935-1221/2009/0021-1970.

Klonowska, I. et al. (2017): Microdiamond on Åreskutan confirms regional UHP metamorphism in the Seve Nappe Complex of the Scandinavian Caledonides. Journal of Metamorphic Geology 35, 541-564, https://doi.org/10.1111/jmg.12244.

Kotková, J., O'Brien, P.J., and Ziemann, M.A. (2011): Diamond and coesite discovered in Saxony-type granulite: Solution to the Variscan garnet peridotite enigma. Geology 39, 667670, https://doi.org/10.1130/G31971.1.

Kotková, J., Škoda, R., and Machovič, V. (2014): Kumdykolite from the ultrahigh-pressure granulite of the Bohemian Massif. American Mineralogist 99, 1798-1801, https://doi.org/10.2138/am.2014.4889.

Krippner, A., Meinhold, G., Morton, A.C., Russell, E., and von Eynatten, H. (2015): Grain-size dependence of garnet composition revealed by provenance signatures of modern stream 
sediments from the western Hohe Tauern (Austria). Sedimentary Geology 321, 25-38, https://doi.org/10.1016/j.sedgeo.2015.03.002.

Krippner, A., Meinhold, G., Morton, A.C., Schönig, J., and von Eynatten, H. (2016): Heavy minerals and garnet geochemistry of stream sediments and bedrocks from the Almklovdalen area, Western Gneiss Region, SW Norway: Implications for provenance analysis. Sedimentary Geology 336, 96-105, https://doi.org/10.1016/j.sedgeo.2015.09.009.

Kroner, U., and Romer, R.L. (2013): Two plates — Many subduction zones: The Variscan orogeny reconsidered. Gondwana Research 298-329, https://doi.org/10.1016/j.gr.2013.03.001.

Kröner, A., and Willner, A.P. (1998): Time of formation and peak of Variscan HP-HT metamorphism of quartz-feldspar rocks in the central Erzgebirge, Saxony, Germany. Contributions to Mineralogy and Petrology 132, 1-20, https://doi.org/10.1007/s004100050401.

Lang, H.M., and Gilotti, J.A. (2015): Modeling the exhumation path of partially melted ultrahighpressure metapelites, North-East Greenland Caledonides. Lithos 226, 131-146, https://doi.org/10.1016/j.lithos.2014.10.010.

Lathe, C. et al. (2005): The influence of $\mathrm{OH}$ in coesite on the kinetics of the coesite-quartz phase transition. American Mineralogist 90, 36-43, https://doi.org/10.2138/am.2005.1662.

Liati, A., and Gebauer, D. (2009): Crustal origin of zircon in a garnet peridotite: a study of U-Pb SHRIMP dating, mineral inclusions and REE geochemistry (Erzgebirge, Bohemian Massif). European Journal of Mineralogy 21, 737-750, https://doi.org/10.1127/09351221/2009/0021-1939. 
Linnemann, U. et al. (2012). The Cambrian to Devonian odyssey of the Brabant Massif within Avalonia: A review with new zircon ages, geochemistry, Sm-Nd isotopes, stratigraphy and $\begin{array}{llll}\text { palaeogeography. } & \text { Earth-Science } & \text { Reviews } & 112,\end{array}$ https://doi.org/10.1016/j.earscirev.2012.02.007.

Liou, J.G., Ernst, W.G., Zhang, R.Y., Tsujimori, T., and Jahn, B.M. (2009): Ultrahigh-pressure minerals and metamorphic terranes-the view from China. Journal of Asian Earth Sciences 35, 199-231, https://doi.org/10.1016/j.jseaes.2008.10.012.

Liou, J.G., and Zhang, R.Y. (1996): Occurrences of intergranular coesite in ultrahigh-P rocks from the Sulu region, eastern China: Implications for lack of fluid during exhumation. American Mineralogist 81, 1217-1221, https://doi.org/10.2138/am-1996-9-1020.

Liu, P., Massonne, H.-J., Zhang, J., Wu, Y., and Jin, Z. (2017): Intergranular coesite and coesite inclusions in dolomite from the Dabie Shan: Constraints on the preservation of coesite in UHP rocks. Terra Nova 29, 154-161, https://doi.org/10.1111/ter.12258.

Massonne, H.-J. (2001): First find of coesite in the UHP metamorphic area of the central Erzgebirge, Germany. European Journal of Mineralogy 13, 565-570, https://doi.org/10.1127/0935-1221/2001/0013-0565.

Massonne, H.-J. (2003): A comparison of the evolution of diamondiferous quartz-rich rocks from the Saxonian Erzgebirge and the Kokchetav Massif: are so-called diamondiferous gneisses magmatic rocks? Earth and Planetary Science Letters 216, 347-364, https://doi.org/10.1016/S0012-821X(03)00512-0. 
Massonne, H.-J. (2011): German part of the Saxonian Erzgebirge in International Eclogite Conference, 9th, Pre-Conference Excursion: Mariánské Lázně, Czech Republic. Geolines 23, 29-59.

Massonne, H.J., Kennedy, A., Nasdala, L., and Theye, T. (2007): Dating of zircon and monazite from diamondiferous quartzofeldspathic rocks of the Saxonian Erzgebirge-hints at burial and exhumation velocities, https://doi.org/10.1180/minmag.2007.071.4.407.

Mosenfelder, J.L. (2000): Pressure dependence of hydroxyl solubility in coesite. Physics and Chemistry of Minerals 27, 610-617, https://doi.org/10.1007/s002690000105.

Mosenfelder, J.L., Schertl, H.P., Smyth, J.R., and Liou, J.G. (2005): Factors in the preservation of coesite: The importance of fluid infiltration. American Mineralogist 90, 779-789, https://doi.org/10.2138/am.2005.1687.

Nasdala, L., and Massonne, H.-J. (2000): Microdiamonds from the Saxonian Erzgebirge, Germany: in situ micro-Raman characterisation. European Journal of Mineralogy 12, 495498, https://doi.org/10.1127/0935-1221/2000/0012-0495.

O'Brien, P.J., and Ziemann, M.A. (2008): Preservation of coesite in exhumed eclogite: insights from Raman mapping. European Journal of Mineralogy 20, 827-834, https://doi.org/10.1127/0935-1221/2008/0020-1883.

Okay, A.I. (1993): Petrology of a diamond and coesite-bearing metamorphic terrain: Dabie Shan, China. European Journal of Mineralogy 5, 659-675.

Schmädicke, E., Mezger, K., Cosca, M.A., and Okrusch, M. (1995): Variscan Sm-Nd and Ar-Ar ages of eclogite facies rocks from the Erzgebirge, Bohemian Massif. Journal of Metamorphic Geology 13, 537-552, https://doi.org/10.1111/j.1525-1314.1995.tb00241.x. 
Schönig, J., Meinhold, G., von Eynatten, H., and Lünsdorf, N.K. (2018a): Tracing ultrahighpressure metamorphism at the catchment scale. Scientific Reports 8, 2931, https://doi.org/10.1038/s41598-018-21262-8.

Schönig, J., Meinhold, G., von Eynatten, H., and Lünsdorf, N.K. (2018b): Provenance information recorded by mineral inclusions in detrital garnet. Sedimentary Geology 376, 32 49, https://doi.org/10.1016/j.sedgeo.2018.07.009.

Schönig, J., von Eynatten, H., Meinhold, G., and Lünsdorf, N.K. (2019): Diamond and coesite inclusions in detrital garnet of the Saxonian Erzgebirge, Germany. Geology 47, 715-718, https://doi.org/10.1130/G46253.1.

Spear, F.S. (1993): Metamorphic Phase Equilibria and Pressure-Temperature-Time Paths. Mineralogical Society of America, Monograph 1, Washington, DC.

Stöckhert, B., Trepmann, C.A., and Massonne, H.-J. (2009): Decrepitated UHP fluid inclusions: about diverse phase assemblages and extreme decompression rates (Erzgebirge, Germany). Journal of Metamorphic Geology 27, 673-684, https://doi.org/10.1111/j.15251314.2009.00835.x.

Tichomirowa, M., Whitehouse, M., Gerdes, A., and Schulz, B. (2018): Zircon (Hf, O isotopes) as melt indicator: Melt infiltration and abundant new zircon growth within melt rich layers of granulite-facies lenses versus solid-state recrystallization in hosting amphibolite-facies gneisses (central Erzgebirge, Bohemian Massif). Lithos 302, 65-85, https://doi.org/10.1016/j.lithos.2017.12.020. 
Tolosana-Delgado, R., von Eynatten, H., Krippner, A., and Meinhold, G. (2018): A multivariate discrimination scheme of detrital garnet chemistry for use in sedimentary provenance analysis. Sedimentary Geology 375, 14-26, https://doi.org/10.1016/j.sedgeo.2017.11.003.

von Eynatten, H., Pawlowsky-Glahn, V., and Egozcue, J.J. (2002): Understanding perturbation on the simplex: A simple method to better visualize and interpret compositional data in ternary diagrams. $\quad$ Mathematical Geology $\quad 34, \quad 249-257$, https://doi.org/10.1023/A:1014826205533.

Willner, A.P., Rötzler, K., and Maresch, W.V. (1997): Pressure-temperature and fluid evolution of quartzo-feldspathic metamorphic rocks with a relic high-pressure, granulite-facies history from the Central Erzgebirge (Saxony, Germany). Journal of Petrology 38, 307-336, https://doi.org/10.1093/petroj/38.3.307.

Willner, A.P., Krohe, A., and Maresch, W.V. (2000): Interrelated P-T-t-d paths in the Variscan Erzgebirge dome (Saxony, Germany): Constraints on the rapid exhumation of high-pressure rocks from the root zone of a collisional orogen. International Geology Review 42, 64-85, https://doi.org/10.1080/00206810009465070.

Ye, K. et al. (2000): Large areal extent of ultrahigh-pressure metamorphism in the Sulu ultrahighpressure terrane of East China: new implications from coesite and omphacite inclusions in zircon of granitic gneiss. Lithos 52, 157-164, https://doi.org/10.1016/S0024-4937(99)000894.

\section{FIGURE CAPTIONS}


Figure 1. Maps showing the location and outline of the study area. A: Simplified map of the northern Central European Variscides after Linnemann et al. (2012) with the location of the Erzgebirge marked by a red asterisk. Inset shows Europe with the map section indicated by the red box. B: Tectonometamorphic units subdividing the Saxonian Erzgebirge after Willner et al. (2000). Red box defines the map section of the geological map in Fig. 1C. C: Geological map of the area around the Saidenbach reservoir in the central Saxonian Erzgebirge with modern sand sampling locations marked by yellow asterisks after Schönig et al. (2019).

Figure 2. Chemistry of coesite-bearing detrital garnet grains. Compositions were determined at nine spots per garnet grain, except garnet \#32 of the 250-500 $\mu \mathrm{m}$ fraction from sample JS-Erz-3s, and are given in molar proportions for the upper ternary plots $\left(\mathrm{X}_{\mathrm{Fe}}-\mathrm{X}_{\mathrm{Ca}}-\mathrm{X}_{\mathrm{Mg}}\right)$ and the lower scatter plots $\left(\mathrm{X}_{\mathrm{Fe}} / \mathrm{X}_{\mathrm{Mg}}\right.$ versus $\left.\mathrm{X}_{\mathrm{Mn}} / \mathrm{X}_{\mathrm{Mg}}\right)$. Garnet grains of the 63-125 $\mu \mathrm{m}$ fraction are labelled by a circle, those of the $125-250 \mu \mathrm{m}$ fraction by a square, and those of the $250-500 \mu \mathrm{m}$ fraction by a triangle. For comparison, $95 \%$ confidence ellipsoids and ellipses of garnet compositions from local crystalline rocks are shown, whereas the confidence ellipse of micaschist covers the entire scatter plot. Location and garnet composition of local crystalline rocks are given in Table A.2 (see Appendix A). Ternary plots in the central part illustrate the probabilities of individual garnet compositions of belonging to three major metamorphic source rock groups (eclogite, amphibolite, or granulite facies) based on the multivariate discrimination scheme after Tolosana-Delgado et al. (2018). As an example, point 'A' and 'B' are given in the left diagram: 'A' means similar probabilities for all three major metamorphic source rock groups and 'B' means similar probabilities for being derived from eclogite and granulite facies sources but zero probability for an amphibolite facies source. Garnet compositions belonging to grains which show compositional 
contrast to diamond-bearing paragneisses and eclogites are numbered and marked by dashed envelopes. Additional ternary plots considering the $\mathrm{X}_{\mathrm{Mn}}$ component (perturbed after von Eynatten et al., 2002) are shown in Fig. A.1 (see Appendix A).

Figure 3. Chemistry of diamond-bearing detrital garnet grains. Compositions were determined at nine spots per garnet grain and are given in molar proportions for the upper ternary plots $\left(\mathrm{X}_{\mathrm{Fe}}-\right.$ $\left.\mathrm{X}_{\mathrm{Ca}}-\mathrm{X}_{\mathrm{Mg}}\right)$ and the lower scatter plots $\left(\mathrm{X}_{\mathrm{Fe}} / \mathrm{X}_{\mathrm{Mg}}\right.$ versus $\left.\mathrm{X}_{\mathrm{Mn}} / \mathrm{X}_{\mathrm{Mg}}\right)$. Garnet grains of the $63-125 \mu \mathrm{m}$ fraction are labelled by a circle, those of the $125-250 \mu \mathrm{m}$ fraction by a square, and those of the $250-500 \mu \mathrm{m}$ fraction by a triangle. For comparison, $95 \%$ confidence ellipsoids and ellipses of garnet compositions from local crystalline rocks are shown, whereas the confidence ellipse of micaschist covers the entire scatter plot. Location and garnet composition of local crystalline rocks are given in Table A.2 (see Appendix A). Ternary plots in the central part illustrate the probabilities of individual garnet compositions of belonging to three major metamorphic source rock groups (eclogite, amphibolite, or granulite facies) based on the multivariate discrimination scheme after Tolosana-Delgado et al. (2018). Garnet compositions belonging to grains which show compositional contrast to diamond-bearing paragneisses and eclogites are numbered and marked by dashed envelopes. Additional ternary plots considering the $\mathrm{X}_{\mathrm{Mn}}$ component (perturbed after von Eynatten et al., 2002) are shown in Fig. A.2 (see Appendix A).

Figure 4. Photomicrographs and Raman images of cristobalite-, kokchetavite-, and kumdykolitebearing garnet grains. A: Three $\mathrm{SiO}_{2}$ polymorphs in garnet $\# 123$ of the $250-500 \mu \mathrm{m}$ fraction from sample JS-Erz-3s. White pixels in Raman image correspond to an unidentified phase. B:

Diamond-bearing polyphase inclusion co-existing with cristobalite- and disordered $\mathrm{SiO}_{2}$-bearing polyphase inclusion in garnet \#110 of the 125-250 $\mu \mathrm{m}$ fraction from sample JS-Erz-9s. White 
pixels correspond to inhomogeneity in the diamond spectra and interference with the phlogopitebiotite spectrum. Pale blue pixels belong to apatite. C: Cristobalite-, kokchetavite-, and kumdykolite-bearing polyphase inclusions in garnet \#92 of the $250-500 \mu \mathrm{m}$ fraction of sample JS-Erz-9s. White pixels in Raman image correspond to a not identified phase. D: Kokchetavitebearing polyphase inclusion in garnet \#66 of the 125-250 $\mu \mathrm{m}$ fraction from sample JS-Erz-3s.

Figure 5. Chemistry of cristobalite-, kokchetavite-, and kumdykolite-bearing detrital garnet grains. Compositions were determined at one spot per garnet grain and are given in molar proportions. Garnet grains of the $63-125 \mu \mathrm{m}$ fraction are labelled by a circle, those of the $125-$ $250 \mu \mathrm{m}$ fraction by a square, and those of the $250-500 \mu \mathrm{m}$ fraction by a triangle. For comparison, $95 \%$ confidence ellipsoids and ellipses of garnet compositions from local crystalline rocks are given. Datasets of detrital and crystalline garnet grains are given in Tables A.1 and A.2 (see Appendix A).

\section{Tables}

Table 1. Summary of detrital UHP garnet grains from the central Saxonian Erzgebirge. 
Table 1. Summary of detrital ultrahigh-pressure garnets

\begin{tabular}{|c|c|c|c|c|c|}
\hline $\begin{array}{l}\text { Sample } \\
\text { number }\end{array}$ & $\begin{array}{l}\text { grain-size } \\
\text { fraction }\end{array}$ & $\begin{array}{l}\text { screened } \\
\text { garnets } \\
\text { (n) }\end{array}$ & $\begin{array}{l}\text { inclusion- } \\
\text { bearing } \\
\text { garnets (\%) }\end{array}$ & $\begin{array}{l}\text { coesite- } \\
\text { bearing } \\
(n)\end{array}$ & $\begin{array}{l}\text { diamond- } \\
\text { bearing } \\
\text { (n) }\end{array}$ \\
\hline JS-Erz-3s & $63-125 \mu \mathrm{m}$ & 318 & 31 & 5 & 0 \\
\hline JS-Erz-3s & $125-250 \mu \mathrm{m}$ & 200 & 50 & 17 & 0 \\
\hline JS-Erz-3s & $250-500 \mu \mathrm{m}$ & 154 & 65 & 17 & 0 \\
\hline JS-Erz-5s & $63-125 \mu \mathrm{m}$ & 330 & 30 & 4 & 0 \\
\hline JS-Erz-5s & $125-250 \mu \mathrm{m}$ & 209 & 48 & 1 & 0 \\
\hline JS-Erz-5s & $250-500 \mu \mathrm{m}$ & 117 & 85 & 2 & 0 \\
\hline JS-Erz-6s & $63-125 \mu \mathrm{m}$ & 313 & 32 & 4 & 0 \\
\hline JS-Erz-6s & $125-250 \mu \mathrm{m}$ & 172 & 58 & 0 & 0 \\
\hline JS-Erz-6s & $250-500 \mu \mathrm{m}$ & 118 & 85 & 3 & 0 \\
\hline JS-Erz-8s & $63-125 \mu \mathrm{m}$ & 320 & 31 & 16 & 0 \\
\hline JS-Erz-8s & $125-250 \mu \mathrm{m}$ & 200 & 50 & 2 & 0 \\
\hline JS-Erz-8s & $250-500 \mu \mathrm{m}$ & 112 & 89 & 5 & 0 \\
\hline JS-Erz-9s & $63-125 \mu \mathrm{m}$ & 419 & 24 & 1 & 4 \\
\hline JS-Erz-9s & $125-250 \mu \mathrm{m}$ & 166 & 60 & 0 & 22 \\
\hline JS-Erz-9s & $250-500 \mu \mathrm{m}$ & 120 & 83 & 0 & 27 \\
\hline JS-Erz-13s & $63-125 \mu \mathrm{m}$ & 292 & 34 & 0 & 0 \\
\hline JS-Erz-13s & $125-250 \mu \mathrm{m}$ & 160 & 63 & 4 & 0 \\
\hline JS-Erz-13s & $250-500 \mu \mathrm{m}$ & 126 & 79 & 6 & 0 \\
\hline JS-Erz-14s & $63-125 \mu \mathrm{m}$ & 206 & 49 & 0 & 0 \\
\hline JS-Erz-14s & $125-250 \mu \mathrm{m}$ & 138 & 72 & 2 & 0 \\
\hline JS-Erz-14s & $250-500 \mu \mathrm{m}$ & 108 & 93 & 4 & 1 \\
\hline total & $63-500 \mu \mathrm{m}$ & 4298 & 58 & 93 & 54 \\
\hline average & $63-125$ & 314 & 33 & 4 & 1 \\
\hline average & $125-250$ & 178 & 57 & 4 & 3 \\
\hline average & $250-500$ & 122 & 83 & 5 & 4 \\
\hline
\end{tabular}



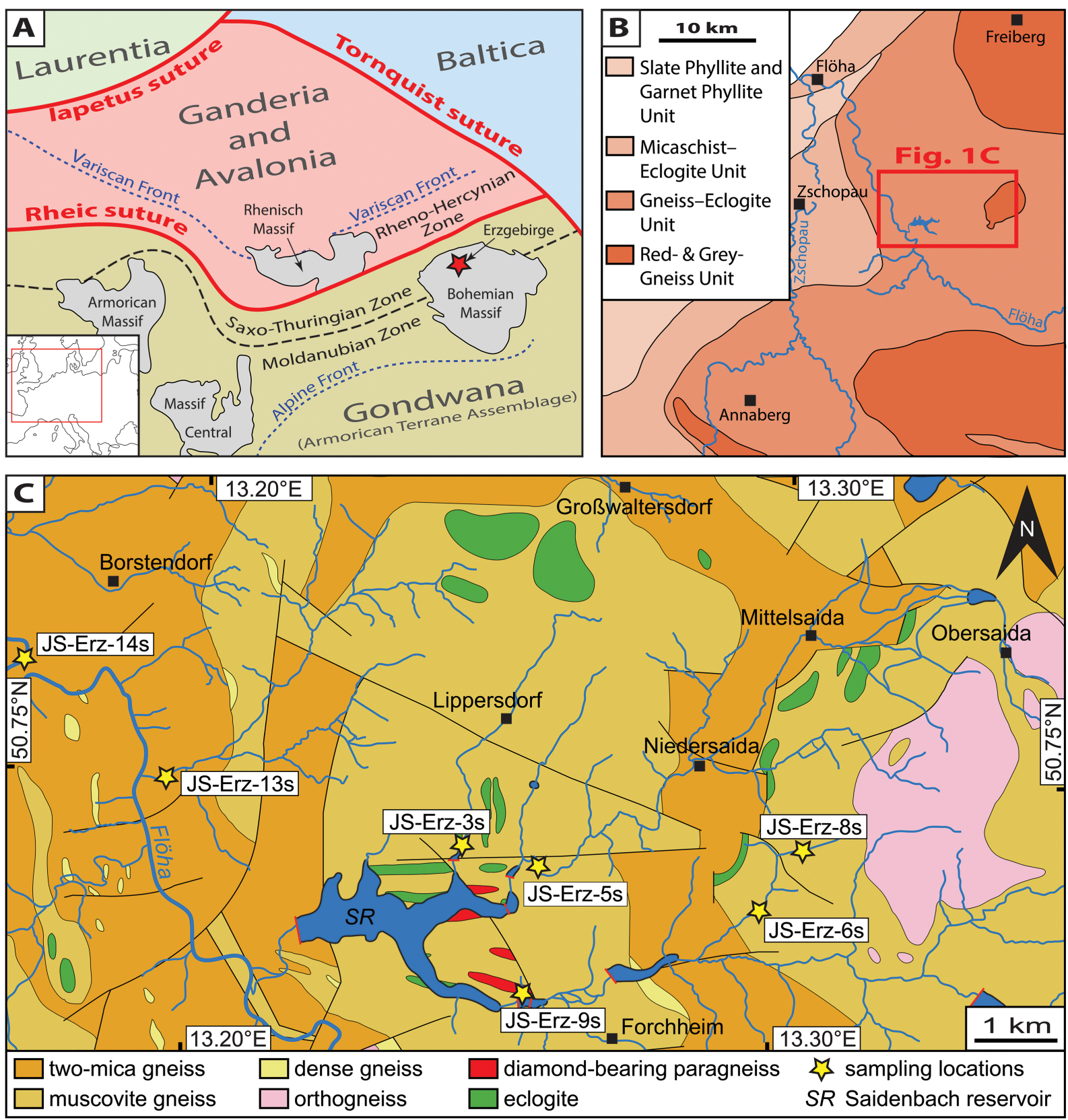

Figure 1 

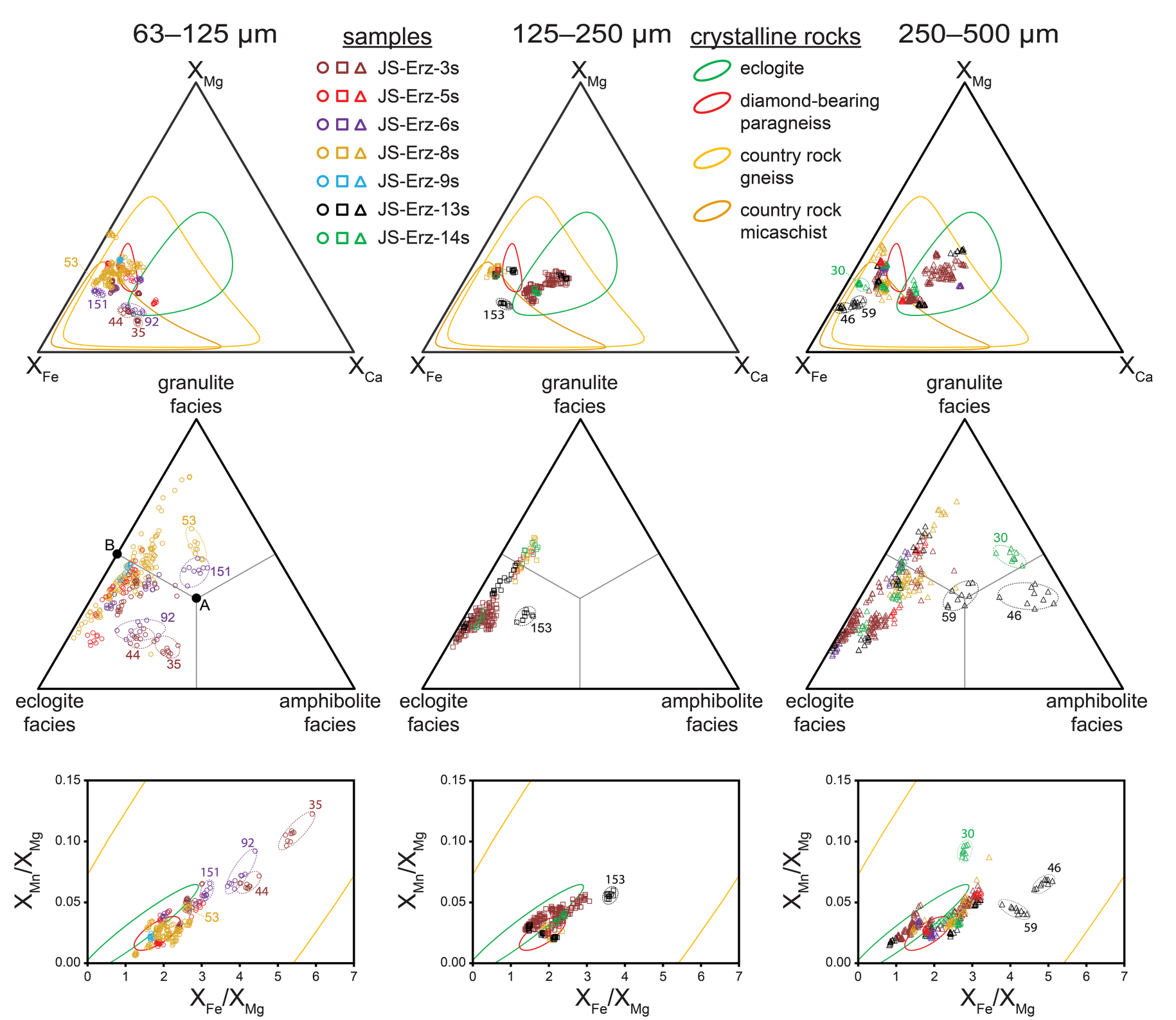

Figure 2 

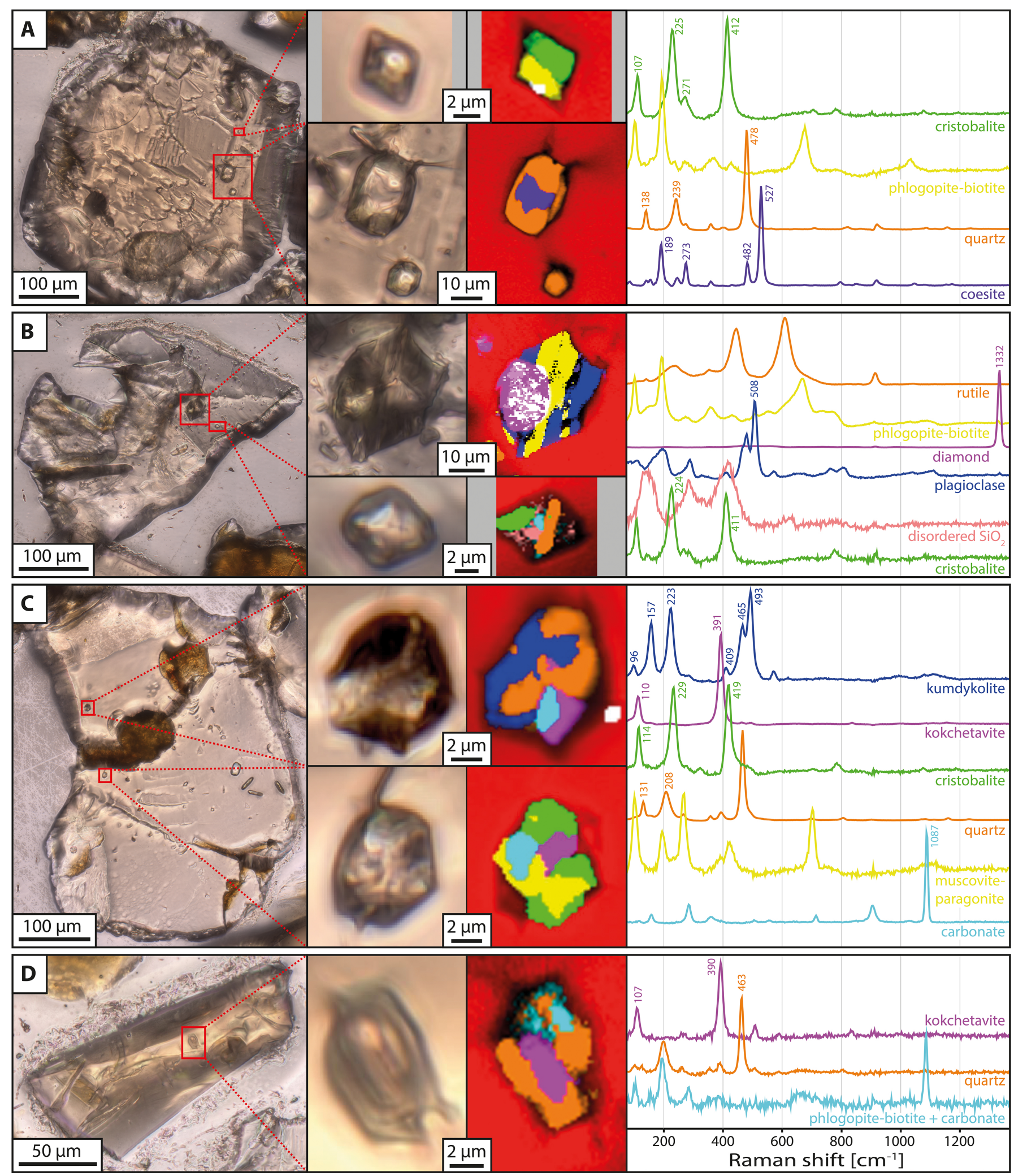

Figure 4 

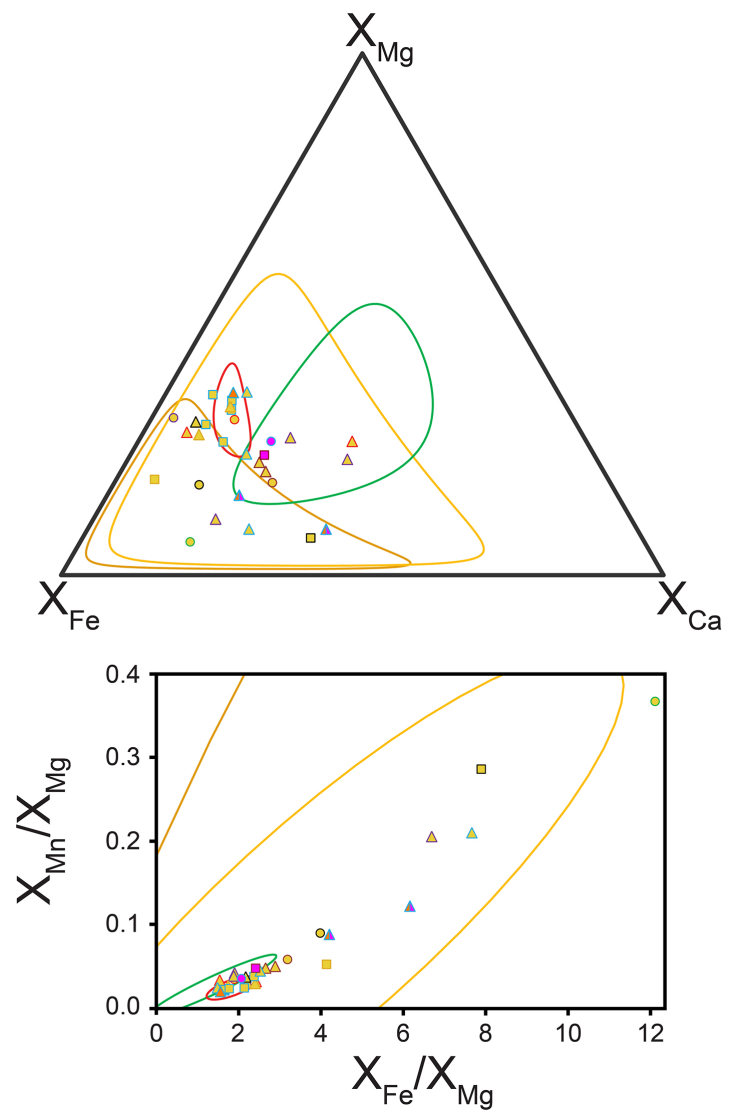

samples

O $\square \Delta$ JS-Erz-3s

O $\square \Delta$ JS-Erz-5s

O $\triangle \Delta$ JS-Erz-6s

$0 \square \Delta$ JS-Erz-8s

O $\square \Delta$ JS-Erz-9s

O $\square \Delta$ JS-Erz-13s

O $\square \Delta$ JS-Erz-14s

inclusion types

- $\triangle$ cristobalite

- $\Delta$ kokchetavite

- $\triangle$ kumdykolite

crystalline rocks

$\checkmark$ eclogite

$\checkmark$ diamondbearing paragneiss

country rock gneiss

$O$ country rock micaschist

Figure 5 